\title{
EXPERT SYSTEM FOR MANAGING LOGISTIC PROCESSES
}

\author{
Drage T. Petreski ${ }^{\mathrm{a}}$, Andrej P. lliev ${ }^{\mathrm{b}}$, \\ Lazar B. Gjurov ${ }^{\mathrm{c}}$, Jugoslav Z. Ackoski, \\ Military Academy „General Mihailo Apostolski“, \\ Skopje, Republic of Macedonia, \\ Aleksandra D. Petreska ${ }^{e}$, \\ Faculty of Electrical Engineering and Information Technologies, \\ Skopje, Republic of Macedonia \\ a e-mail: drage_petreski@yahoo.com, \\ ORCID iD: (10http://orcid.org/0000-0002-5830-1389 \\ b e-mail: andrej220578@gmail.com, \\ ORCID iD: (Dhttp://orcid.org/0000-0002-7917-1966 \\ c e-mail: lazar.gjurov@gmail.com, \\ ORCID iD: (ohttp://orcid.org/0000-0002-7608-2802 \\ d e-mail: jugoslav.ackoski@ugd.edu.mk, \\ ORCID iD: (1)http://orcid.org/0000-0003-2782-3739 \\ e e-mail: petreska_aleksandra@yahoo.com \\ ORCID iD: (10http://orcid.org/0000-0003-3315-8966
}

DOI: 10.5937/vojtehg64-10258

FIELD: Defense Management - Logistics

ARTICLE TYPE: Professional Paper

ARTICLE LANGUAGE: English

Abstract:

The management of resources is one of the three most important areas of management in defense, besides the information management and the human resources management.

By defining the concepts of Information Systems, decision support systems, expert systems, as well as their component parts, the possibilities they offer and the way of their functioning, we have made an attempt to present the Logistics Information System as an Expert System. The growing importance and the need for fast, timely and continuous logistic support of military units imposes the need for introducing a computer automated system which will increase the work efficiency and will save time to managers and decision makers at all levels of the Command and Control in the Ministry of Defense of the Republic of Macedonia. Having accurate information in appropriate time, especially regarding the availability of material resources, is a prerequisite for effectively managing logistic processes and for successfully performing tasks by military units.

Key words: information systems, systems, resources, military, manager, management of resources, logistics, information use, expert systems. 


\section{Introduction}

The management of modern business processes must constantly find solutions to all turbulence in the working environment and pay attention to developing one's own strategy in the area of: operations, automation, integration, information and utilization of resources.

Knowledge, information and achievements are an imperative of our time and a major precondition for success in the work of any individual or organization. Today, business entities are trying to communicate quickly and accurately to send all the information to necessary users.

This kind of needs exists in every sphere of the human activity: defense, science, technology, economics, arts, history, and more. The opportunity is available for instant access to information and its rapid exchange today, which is not a privilege of individuals or groups, but generally is a common good for everyone.

The rapid development of technology of computer systems created an opportunity of their participation in the transmission of information. Applications for this purpose are being developed in various fields of life. Modern scientific and technological development imposes a substantial change in the manner of data collection, processing and presenting.

The first rudiments of automated flow of information were made in the logistics system in the United States Army in terms of planning. The complexity of planning logistic support in multiple phase operations of modern armies overcomes the method of board and pen that was used before. Modern planning procedures depend on the use of automated programs to ensure their speed and to include all the details which have to match the pace of the operation (Edwards, 2004).

For quality management decisions, we need quality knowledge which is inherent to human experts. This knowledge can be included in the software for supporting decision making. Software that integrates the knowledge from experts is called a support system in decision-making based on knowledge (Knowledge Based Decision Support System KBDSS) or an intelligent system for supporting decision-making (Intelligent Decision Support System - IDSS). Support systems for decision making based on knowledge can increase the capabilities for decision-making by supplying a software tool that will directly support the decision.

One of the main features of the decision-making process is based on information. Timely and accurate information is a key element and a prerequisite in the process of decision-making and the management of resources. Without the necessary information, data and parameters, it is impossible to make a decision.

A system for decision support is one of the most modern tools used in decision-making because it allows the integration of knowledge and experience of the decision-maker with the database, which facilitates the decision-making process. 
The most commonly used software tools for supporting decisionmaking are expert systems. They are used in all areas of operation, in defense management as well, especially in providing logistic support. Logistics information management is a continuous process of: collecting, processing, preserving, analysing and presenting information on the course of the operation of the planned logistical support at all levels of command and control.

Modern logistics systems and processes are almost unimaginable without adequate information support. A huge amount of information which has to be processed daily, the need for quality management of resources and quick decision-making cannot be realized without work environment based on information technology. It supports the decisionmaking bodies and optimizes the management of logistic support.

The duty of all responsible authorities is to define precisely information objects (vehicles, persons, units, etc.), their characteristics that will be monitored and the form of reports which will be submitted to higher levels. The Logistics Information System as an expert system is a computersupported system the goal of which is to support the management of logistic activities. It provides an opportunity for permanent optimization and improvement of working processes and the logistic support operation in general. Our aim is to present the logistic information system as an expert system, which is an important link in the decision-making process in the Ministry of Defense and the Army of the Republic of Macedonia.

\section{Categories of research}

Permanent social and technological development which attempt to promote and facilitate work imply the need to introduce information systems that contribute to speed, timely and accurate receiving, processing and distributing information to all levels of management.

In the following part of our paper, we will examine several categories relevant to the subject of research: information system, decision support system, expert system, management, logistics management and logistics information system.

The International Federation for Information Processing - IFIP defines the information system as follows: The information system is a system that collects, complements, stores, processes and delivers information relevant to the organization and society, in order to be available and usable by anyone who wants to use it, including the management, customers, employees and others.

The Information System is an active social system that may or may not have to use information technology (International Federation for Information Processing: Technical Committees and Working GroupsInformation Systems, 2013). 
The information system is a set of methods, procedures and resources designed to facilitate the achievement of certain goals (Thierauf, 2001).

In terms of the systematic approach, the information system is a sorted set of methods, processes and operations for: collection, storage, processing, transmission and distribution of data in one organization, including equipment used for these purposes and people engaged in these activities (Pojam informacionog sistema, 2013).

The information system should be placed in a way that: it will be understood by all users, will be simple in presentation of information, will be secure and will allow presentation of the processed information in a very short time interval.

There are different divisions of information systems. For example, some authors are dividing modern information systems in: operational information systems and systems for supporting decision-making in management.

Systems for decision support

Decision Support Systems-DSSs represent a powerful tool in making complex decisions and they are used in many fields, including defense. As an update of various disciplines, primarily management and information science, they have roots in the decision-making theory and are used in various areas of operation from natural sciences, technology, economics to education (Veljović, 2007, p.1).

Systems for decision support are supporting all stages in the decisionmaking process, starting with the stage of formulating the problem through the design phase and the phase of selection, to implementation. Furthermore, they support various processes and styles of decision-making, they are adaptive to new operating needs, easy to use, they enable greater efficiency in the decision-making process, etc. They also need to provide timely information to managers, which would also be accurate, relevant and complete. The information should be shown in a proper form in order to be easily understood and managed (Veljović, 2007, pp.1-2).

Many authors during their development had different interpretations of the term 'system decision support'. Turban gives a very precise definition which, according to him, is: an interactive, flexible and adaptive computer-based information system designed primarily to support the solving of unstructured management problems for improving the decision-making process (Turban, 1995, p.5).

Expert systems

Expert systems in the artificial intelligence are computer programs designed to solve complex problems using reasoning based on expert knowledge which does not follow the procedures developed in the case of conventional programming (Turban, Aronson, 1988, p.15). 
The appearance of expert systems has greatly facilitated the work at places where complex and important decisions are made. These systems represent computer programs that simulate the behavior of persons or organizations with expert knowledge and experience in a particular area. Typically, these systems contain a knowledge base which contains accumulated experience and a set of rules to change the basis of knowledge of each particular situation described in the program. Sophisticated expert systems can be improved by adding knowledge to the base or set of rules.

According to Edward Feigenbaum from Stanford University, one of the best experts in this area, who presents expert systems in the best way, uniting both of the above aspects, expert systems are intelligent computer programs that use the knowledge and procedures of locking to solve complex problems, which require human expertise and skill. The required level of knowledge along with locking mechanism for solving the problem can be considered as a model which is simulating the best expert in that area (Mišković, 2013, p.150).

Besides the general division of expert systems which are divided into those that analyze a problem and those which perform a synthesis in the process of solving the problem, the expert systems are distributed based on the type of information they offer, such as: independent, consulting and systems "would be if ..." (Mišković, 2013, p.139).

The key components of each expert system are: (Fig.1) knowledge base, deduction mechanism and user interface (King, 1989, p.21).

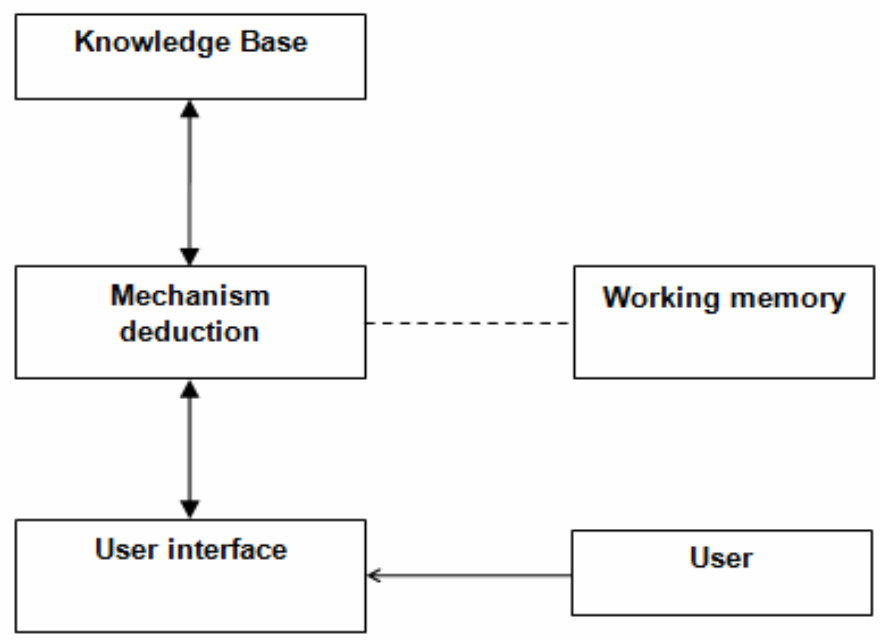

Figure 1 - The basic structure of expert systems

Puc. 1 - Базовая структура экспертной системы

Slika 1 - Osnovna struktura ekspertskog sistema 
The knowledge base is the basis of the expert system and contains the necessary knowledge for understanding, formulation and problemsolving, which contains information and regulations for the specific problem area (real system) that we want to make. Besides general knowledge, it contains special heuristics - rules and subjective assessments that guide the knowledge.

A deduction mechanism has a task to find the right knowledge from the knowledge base and to develop new knowledge. It can be said that the mechanism of deduction is the most important activity which takes place in the expert system. Thanks to this activity, expert systems are intelligent systems. The process of locking is the one which animates the otherwise lifeless knowledge stored in the knowledge base and which knows how to apply it to the existing problems. Without the process of locking, expert systems would be only an Encyclopedia of information.

The user interface is the third major component of any projected expert system. The main role of this component is to provide simple communication between the system and the user, i.e. to provide the following: easy communication, simple running of the program, control of input and output and quality interpretation of results (King, 1989, pp.22- 23).

The process of expert systems functioning can be divided into the following five components: acquisition of knowledge, presentation / exhibition of knowledge, knowledge processing, interface components and explanation.

\section{Management of logistics information}

Management as a phenomenon is present in nearly every scientific discipline and covers all functions that successful functioning of society depends on. It represents a base of the modern approach to the management and training of organizations in a line with the long-term needs and requirements of the environment.

According to Shermerhorn (Schermerhorn, 2002), management is a process of planning, organizing, managing and controlling the process and use of resources to achieve the objectives. He provides a schematic view of the management process, shown in Figure 2. 


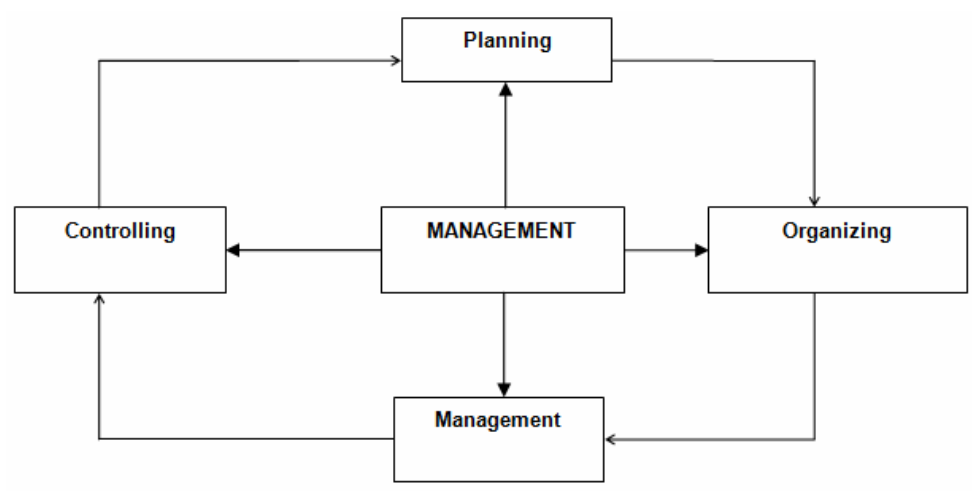

Figure 2 - Schematic representation of the process of managing Puc. 2 - Схематическое изображение процесса управления Slika 2 - Šematski prikaz procesa upravljanja

According to Woodruff and Thomas (Thomas, Woodruff, 1999), managers are responsible for four functions of the management process. Decision-making is the primary job of any manager, no matter the level or function. A decision is always a reaction to a situation, something that should be taken or needs to be changed. In order to make good decisions, managers must be familiar with modern methods and principles of decisionmaking. Modern managerial decision-making is based on scientific principles, quality information and effective assessment processes.

As we already pointed out, management is an essential feature of modern activity of any organization, including the Ministry of Defense and the Army of the Republic of Macedonia.

Logistic support management is a process that includes planning, decision-making, organization, cooperation and coordination, monitoring and reporting the implementation of logistic support. It is a segment in the overall system of defense management, implemented at all decisionmaking levels to optimize logistic support (Ministry of Defence of the Republic of Macedonia, 2011, pp.22-26).

The management of logistics information connects the information technology with logistics processes and enables the authorities to facilitate decision-making, delivering actionable information in real time, as well considering the actual needs for logistic support (Andrejić, et al., 2009 , p.59). The management of logistics information should cover all logistic functions and should enable the link between them and with other functional areas in the defense; hence the need to introduce an information system in logistics or the Logistics Information System.

The logistics Information system is a computer-supported system which completely provides support in managing integrated logistic activities and management with the logistics system. Generating quality reports and timely information necessary for decision-making is the primary task of the logistics information system. 
The mission of the logistics information system in the sphere of defense is seen in the planning, creation, development, monitoring, maintenance or continuous support of efficient and effective defense forces (Andrejić, et al., 2009, p.60).

\section{Logistics information system as an expert system for managing logistics processes}

Working with logistics information is a continuous process of collecting, processing, preservation, analysis and presentation of information on the course of operation of the planned logistic support at all levels. All this is aimed at supporting the decision-making bodies and at the optimization of logistics management support. The duty of all authorities is to define precisely the information objects (vehicles, persons, units) and their characteristics which will be monitored in the form of reports submitted to higher levels. The periodic and additional records, reports and collected information are in accordance with the needs and the available data.

Modern working processes, modernization of institutions, influences from developed countries, emerging challenges and trends show the need for keeping up with these developments in all spheres of society, including the sphere of defense.

The problems of today's working practices (characterized by outdated methods, business techniques, technology and systems, data inconsistency, poor visibility of fixed assets and supplies, lack of accurate information and slow flow of information) have imposed the necessity of introducing an automated information system that will satisfy the following needs and requirements: compatibility with the NATO standards, the need for accurate and timely data, precision in planning, budget versus reality, better consumption control, sustainable and proactive planning, procurement and monitoring of supplies.

In accordance with the Project for improvement of the Macedonian infrastructure and business services (MIESU - Macedonian Infrastructure and Enterprise Services Upgrade) two subprojects were initiated and conducted, related to: upgrading the infrastructure of Global Communications Information System (GCIS) and implementation of the application for the Logistics information system (The Government of the Republic of Macedonia, 2011, pp.4-5).

The aim of the project concerning the global information communication system was building new IT infrastructure and improving the existing one in the country for the needs of the Ministry of Defence and the Army of the Republic of Macedonia. Now the entire network and communications equipment and services are based on open standards and they are compatible with the existing global information infrastructure. 
The purpose of the rest of the project was configuring, developing and constructing a logistics information system which will be implemented in the Ministry of Defense and the Army of the Republic of Macedonia. It is planned that this system consists of three subsystems: Information supply systems (ISS), Information maintenance system (IMS) and Information system for movement and transportation (ISMT).

These three subsystems will be developed successively. The first phase is currently being implemented, which is the development and implementation of the Information Supply System. This system provides support for managing materials, resources and requirements for procurement and supply of background material items for the Ministry of Defense and the Army.

The Logistics information system provides support for the automated information system for the following functional processes: forecasting and planning materials, requirements for the purchase of stocks, origin of supply, contracts, purchasing, receiving, inventory transfers between units, delivery / dispensing material items, requests for supply recharge and asset management.

These eleven procedural models are closely interrelated and there is a need for exchanging information. The interconnection between the processes is shown in the diagram below (Figure 3) in order to present the flow of information between each model.

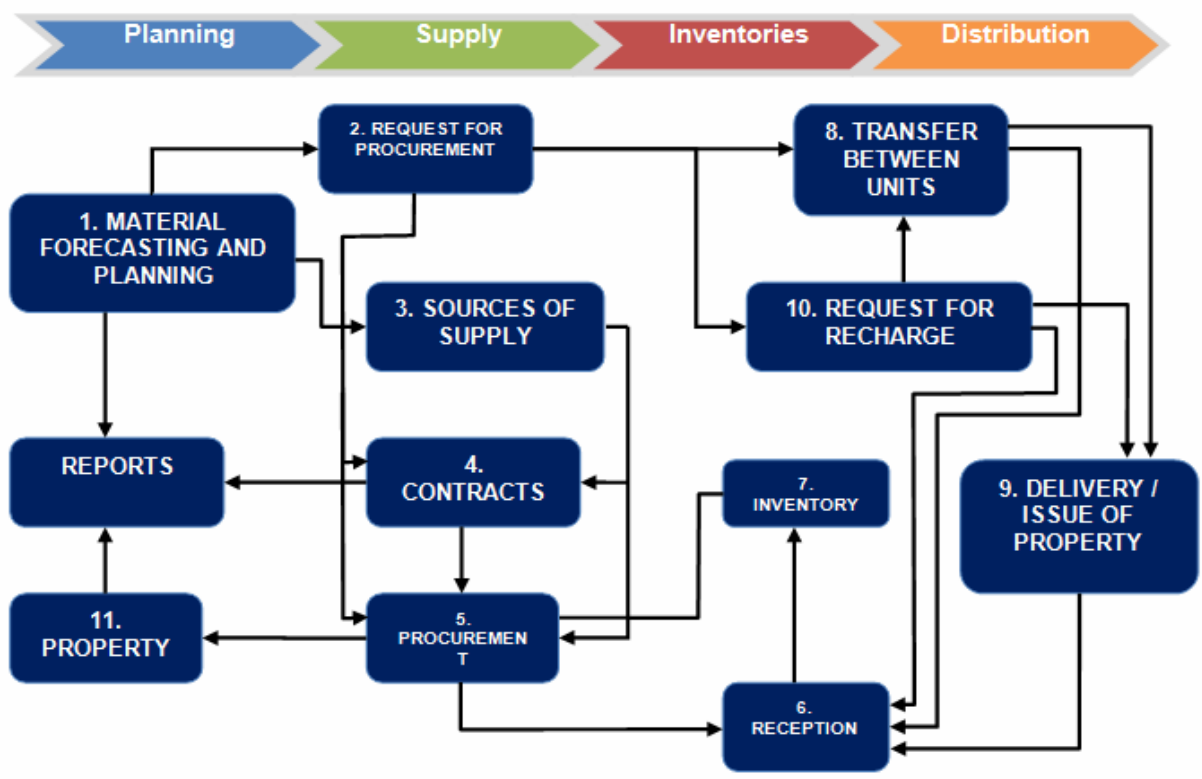

Figure 3 - Procedural areas of the Logistics Information System

Puc. 3-Процессные области Логистической информационной системы

Slika 3 - Procesne oblasti Logističkog informacionog sistema 
In the framework of the logistics information system based on the needs for accessing data and their analysis in daily operations, the key logistics customers are defined.

The logistics information system has led to changes in the performance of daily tasks of employees in the military, especially those involved in the logistics business processes. Documents and data which used to be processed manually and on paper now are stored electronically in the system for promoting greater efficiency and greater control.

It was already stated that the Logistics information system was based on eleven contractual process areas classified in three modules:

- From finance to control - module which is covering the business areas: integration with financial and material planning and forecasting;

- From procurement to payment - module which is covering the business areas: procurement requirements, sources of supply, contracts, procurement, requests for recharging;

- From admission to delivery - module which is covering the business areas: reception of materials, inventory transfers between units and issuing material delivery and asset management.

Additionally provided requirements are fuel and planning projects (Government of the Republic of Macedonia, 2010).

Let us remember that according to the definition, the expert system is a computer program that simulates the behavior of one person or organization that has expert knowledge and experience in a particular area. Indeed, this definition proves to be correct because the Logistics information system was created by experts whose expertise and experience it incorporated and transformed into a knowledge base which is the basis of this system.

Two groups of experts were involved in the creation of the Logistic information system. First, many experts from different fields: finance, supply management, logistics, procurement, cost management, warehouse management, etc. This group of experts created the user software Dynamics AX. The other group was composed of experts from the Ministry of Defence from the respective areas who incorporated their expertise and long experience to modify the Dynamics $A X$ and to make an adequate knowledge base which is the basis for the Logistic information system.

In the time of establishing the system, the experts provided an opportunity for constant updating and modernization depending on the needs and requirements brought by the new era.

\section{Benefits from the use of the Logistics information system}

Logistics management is considered as a critical link in the process of defense management. For making better decisions and for proper management of resources, the necessary information is required to be 
timely and accurate. Due to the need for the codification of assets and compatibility of the domestic logistics system with the NATO systems, and the need for the accuracy of inventory planning, a project was launched for modernizing the way of working in the field of logistics which resulted in the decision to implement the Logistics information system.

The new Logistics information system has these sets of capabilities: development, construction, implementation and support of eleven agreed processes / modules, fuel management, export data to other systems, prototype of functionality for maintenance, repair and overhaul, as well as determining the needs for the module of transport and distribution.

The list of benefits from the implementation of the Logistics information system is remarkable, but, as some of the most important and greatest benefits, we will mention the following:

- speed and accuracy of data;

- efficiency in the functioning;

- interoperability with NATO;

- reduced operating costs;

- sustainable Logistics information system and architecture that is easy to upgrade;

- benefit on the national level, and others.

In the following part of our paper, we will give a short description for each of the benefits.

\section{Speed and accuracy of data}

The proper planning and forecasting of purposes are essential for the proper resource allocation and management of courses to ensure their rapid and accurate determination. Also an important element is the corresponding warehouses for storing goods providing tactical and strategic flexibility.

The Logistics information system has replaced the outdated system which consisted of a lot of data sources. Their inconsistency, poor visibility of the underlying assets and consumables were replaced with high precision in the planning process, improving the control over the consumption and, very importantly, the sustainable and proactive planning of procurement and monitoring of supplies.

Month-long data updates, slow flow and lack of accurate information are replaced with accurate and timely data given in the Logistics information system which maintains the accuracy in daily operations. All this in reality means that daily transactions in terms of material resources or material lists are transferred to a responsible person with one click, instead of spending time in a time-consuming process. All this affects the 
accuracy of data, because in real time we have precise data about what and where something can be found, going to the tiniest details, for example: Which shelf, room or building has what we are looking for.

\section{Efficient functioning}

Defense forces must be ready at any time to carry out their tasks and missions in a controlled manner, thereby avoiding unwanted situations of lack of exact quantity supplies, ammunition, food, fuel and spare parts. This system forms the basis for the efficient functioning of the armed forces in a way that enables decision makers at every level to have visibility of all necessary data.

Interoperability

The desire of Macedonia to become a NATO member and the change of the mission of the armed forces are leading to the needs for the Army to be flexible in terms of fulfillment of the standards. The system is designed to enable complete management of logistics defense processes and to allow a kind of transformation of the organization of the defense at the strategic level. The Logistics information system significantly improves the interoperability with allied Logistics systems and the codifing standards.

Reduced operating costs

The possibility of obtaining accurate data for the assets in each segment of the Army or unit, warehouse, etc, which contributes to more accurate creation of financial plans and, accordingly, the plans for procurement, which results in proper and economical use of the budget. With visibility of materials on inventories in warehouses, managers are allowed to perform restricted resources from the nearest storehouse, which leads to reduced costs in terms of movement and transport.

\section{Sustainable Logistics information system and architecture that is easy to upgrade}

The Logistics information system, as an expert system, is selected for use in the defense sector because of its scalable architecture that allows extensibility of processes, in addition to the latest trends of modernization and transformation of the Army. 
After the implementation of the first stage, we have already seen a possibility of extending the decision for closing the gap for financial management, transportation and distribution and resources management of selected tracking assets as the next stages of our engagement.

\section{The benefits at the national level}

The state will have a possibility to implement advanced technology available from global partners, such as Hewlett Packard to identify, design and implement technology for transforming and extending the knowledge of employees in the government and in the military sector using the best practices and leading technologies.

\section{Conclusion}

In the decision-making process, it is important to consider alternative solutions, recognize possible consequences of their use and compare options. The process is further complicated with the external environment (new technologies, information systems, advanced research and globalization) and the fact that everything is becoming more and more complex.

Because of all the above reasons, managers are forced to use new techniques and tools for the decision-making process and they need to rely on information technology. Modern logistics systems and processes are unthinkable without adequate information support.

A huge amount of information which needs to be processed daily, the need for quality management of resources and quick decisionmaking, and the reduction of personnel in order to use resources more economically, cannot be realized without adequate support of a quality information system.

Today we spent less energy, time and personnel for processing simple information which would be adequately used in the process of decision-making from the lowest tactical to the strategic level.

With the introduction of the Logistics information system, we will have lower economic costs in the logistics support system. The rapid transmission of information, timely locating the needs of units, available data for the status of resources, affects on reduction of storage material assets in stocks (Andrejić, et al., 2009, p.15).

This application itself was a part of Microsoft software, specifically Microsoft Dynamics AX. This solution was chosen because of several key elements, such as: timing of implementation which entails reduced costs; the fact that it is an integrated ERP (Enterprise Resource 
Planning)-solution concerning financial management, payment and purchasing, and supply chain of logistics; its flexible configuration (application which is global, but adapted to the Macedonian conditions), and in particular the important ladder architecture which allows the extensibility of processes and roles.

The last element relates to the intentions of the Ministry of Defense to integrate all functions of the Logistics system though different stages. Currently, the Logistics information system is in its first phase, which supports the supply area with their supplying subsystems.

\section{References}

Andrejić, D.M., Milenkov A.M., Sokolović S.V., 2009, Logistički informacioni sistem, Beograd, Vojna akademija - Katedra logistike, pp.59-60.

Edwards, J.E., 2004, Combat service support guide - 4 th Edition, Mechanicsburg, PA 17055, USA, Stackpole Books.

Government of Republic of Macedonia, Project: MIESU - Macedonian Infrastructure and Enterprise Services Upgrade, 2011, Skopje, pp.4-5.

Government of Republic of Macedonia, Strategy for development of e-Contents 2010 - 2015, 2010, Ministry of Information Society, Skopje.

International Federation For Information Processing: Technical Committees and Working Groups-Information Systems, Retrieved from:

http://www.ifip.org/index.php?option=com_content\&task=view\&id=185\&ltemid=509, 10.09.2013.

King, D., 1989, Modeling and reasoning: Inegrating Decision support with Experts Systems-Englewood Cliffs, NJ, Prentice-Hall, pp.21-23.

Ministry of Defence on the Republic of Macedonia, 2011, Concept for logistic support of defense of the Republic of Macedonia, Skopje, GS ARM, pp.22-26.

Mišković, V., 2013, Sistemi za podrsku odlucivanju, Beograd, Univerzitet Singidunum, pp.139-150.

Pojam informacionog sistema, Retrieved from:

http://www.znanje.org/knjige/computer/access/access_01/POJAM\%20INFORMACIONO G\%20SISTEMA.htm, 11.10.2013.

Schermerhorn, R.J., 2002, Management Seventh Edition, Marshall Texas, USA, Wiley College. Books.

Thierauf, R., 2001, Effective business intelligence systems, London, Quorum

Thomas, R.R., Woodruff, M.I., 1999, Building a house for diversity, New York, Amacom.

Turban, E., 1995, Decision support and expert systems: management support systems-Englewood Cliffs, N.J., Prentice Hall, p.5.

Turban, E., Aronson, J., 1988, Decision Support Systems and Intelligent SystemsUpper Saddle River, NJ: Prentice Hall, Inc, p.15.

Veljović, A., 2007, Sistem za podršku odlučivanja, Beograd, CET Čitalište 67, pp.1-2. 


\section{ЭКСПЕРТНАЯ СИСТЕМА МЕНАДЖМЕНТА В ЛОГИСТИЧЕСКОМ ПРОЦЕССЕ}

Драге Т. Петрески ${ }^{\mathrm{a}}$, Андрей П. Илиев ${ }^{\mathrm{a}}$, Лазарь Б. Гюров ${ }^{\mathrm{a}}$, Югослав 3. Ацкоски ${ }^{a}$, Александра Д. Петрескаб

а Военная академия „Генерал Михаило Апостолски“,

Скопье, Республика Македония

${ }^{б}$ Факультет электротехники и информационных технологий,

Скопье, Республика Македония

ОБЛАСТЬ: менеджмент в области обороны, логистика

ТИП СТАТЬИ: профрессиональная статья

ЯЗЫК СТАТЬИ: английский

Резюме:

Менеджмент ресурсов наряду с информационным менеджментом и менеджментом персонала является одной из важнейших областей управления в системе обороны.

В результате определения таких понятий как: информационная система, система поддержки принятия решений, модульная система экспериментов, и их составляющих, а также в результате исследований их возможностей и эффективности, предпринята попытка преобразования логистической информационной системы в экпертную систему управления.

Для быстрой, своевременной и бесперебойной логистической поддержки военных подразделений большое значение играет автоматизированная информационная система, повышающая эфффективность работы и экономящая время менеджерам и командующим на принятия решений и мониторине в Министерстве обороны Республики Македония.

Своевременное получение точной информации о наличии материальных ресурсов является главным условием эфрфективного управления логистическим процессом и успешного выполнения поручений, выданных воинскими подразделениями.

Ключевые слова: информационные системы, системы, ресурсы, военные, менеджер, менеджмент логистики, преобразование данных, экспертная система.

\section{EKSPERTSKI SISTEM ZA MENADŽIRANJE LOGISTIČKIH PROCESA}

Drage T. Petreski ${ }^{a}$, Andrej P. Iliev ${ }^{a}$, Lazar B. Gjurov ${ }^{a}$, Jugoslav Z. Ackoski ${ }^{\mathrm{a}}$, Aleksandra D. Petreska ${ }^{\mathrm{b}}$

a Vojna akademija „General Mihailo Apostolski”, Skoplje, Republika Makedonija

${ }^{b}$ Fakultet elektrotehnike i informacionih tehnologija, Skoplje, Republika Makedonija

OBLAST: menadžment u odbrani, logistika

VRSTA ČLANKA: stručni članak

JEZIK ČLANKA: engleski 
Sažetak:

Menadžment resursa predstavlja jednu od tri najvažnije oblasti za menadžment $u$ odbrani, između informatičkog menadžmenta i menadžmenta ljudskim resursima. Preko definisanja pojmova informatički sistem, sistem za podršku odlučivanju, sistem za eksperimentisanje, kao i komponente koje ih sačinjavaju, mogućnosti koje nude i način njihovog funkcionisanja, učinjen je pokušaj da se prevede logistički informatički sistem u ekspertski sistem. Veliki značaj za brzu, pravovremenu i kontinuiranu logističku podršku vojnih jedinica nameće potrebu za uvođenjem informatički automatizovanog sistema koji će da poveća efikasnost u radu i uštedi vreme menadžerima i donosiocima odluka komandovanja i kontrole u Ministarstvu odbrane Republike Makedonije. Pravovremeno raspolaganje tačnim informacijama koje se odnose na raspoloživost materijalnih resursa predstavlja preduslov za efikasno upravljanje logističkim procesima i uspešno izvršavanje zadataka vojnih jedinica.

Ključne reči: informacioni sistemi, sistemi, resursi, vojni, menadžer, menadžment resursa, logistika, koričenje informacija, ekspertski sistem.

Paper received on / Дата получения работы / Datum prijema članka: 13. 02. 2016. Manuscript corrections submitted on / Дата получения исправленной версии работы / Datum dostavljanja ispravki rukopisa: 23. 03. 2016.

Paper accepted for publishing on / Дата окончательного согласования работы / Datum konačnog prihvatanja članka za objavljivanje: 25. 03. 2016.

(C) 2016 The Authors. Published by Vojnotehnički glasnik / Military Technical Courier (www.vtg.mod.gov.rs, втг.мо.упр.срб). This article is an open access article distributed under the terms and conditions of the Creative Commons Attribution license (http://creativecommons.org/licenses/by/3.0/rs/).

() 2016 Авторы. Опубликовано в "Военно-технический вестник / Vojnotehnički glasnik / Military Technical Courier" (www.vtg.mod.gov.rs, втг.мо.упр.срб). Данная статья в открытом доступе и распространяется в соответствии с лицензией "Creative Commons" (http://creativecommons.org/licenses/by/3.0/rs/).

(c) 2016 Autori. Objavio Vojnotehnički glasnik / Military Technical Courier (www.vtg.mod.gov.rs, втг.мо.упр.срб). Ovo je članak otvorenog pristupa i distribuira se u skladu sa Creative Commons licencom (http://creativecommons.org/licenses/by/3.0/rs/).

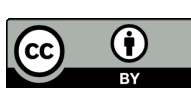

